\title{
Keratoacanthoma - Non surgical treatment modalities
}

\section{Yasmeen Jabeen Bhat}

\begin{abstract}
Department of Dermatology, Sexually transmitted diseases \& Leprosy, Government Medical College Srinagar, University of Kashmir, India
\end{abstract}

Corresponding author: Dr. Yasmeen Jabeen Bhat, E-mail: yasmeenasif76@gmail.com

Sir,

Keratoacanthoma (KA) is a cutaneous squamoproliferative tumor with the potential for spontaneous resolution and needs to be treated due to its resemblance to cutaneous squamous cell carcinoma. It is a unique, benign or borderline malignant neoplasm exhibiting follicular (infundibular/isthmic) differentiation characterized by the involvement of continuous follicular infundibula in multiples. Multiple self-healing squamous epithelioma of Ferguson-Smith (MSSE) is a rare autosomal dominantly inherited disease, almost exclusively reported in patients of Scottish origin, with recurrent, histologically malignant tumours that undergo spontaneous regression [1]. Molecular analyses of MSSE tumours indicate that the MSSE gene is a tumour suppressor gene. Recently, the causative gene for MSSE was identified as TGFBR1, encoding a transmembrane serine/threonine kinase receptor involved in TGF- $\beta$ signaling. UV radiation might play a central role in the tumourigenesis in MSSE, since tumours are localized typically in light-exposed skin areas, but the precise mechanism is not clear [2].

The initial lesions of MSSE are similar to KA and typically localized in light-exposed skin areas. They begin with an acne-like lesion or a reddish macule, developing into a papule and later a nodule with a central crateriform ulcer with rolled edges and often a central horny plug. The tumour is locally destructive and deep local infiltration can be seen. The growth phase is, after a few weeks, followed by spontaneous regression over a period of months leaving pitted scars [3].

The first-line therapy for KA that is simple and well tolerated is conventional surgical excision [4]. It provides histopathologic confirmation of tumor removal. Mohs micrographic surgery is usually reserved for patients in whom a tissue-sparing procedure is desired [5]. Alternative therapies include electrodessication and curettage, intralesional pharmacologic therapy, ionizing radiation, and topical agents, but all these lack the histopathologic confirmation of the tumor. Intralesional therapy with $5-\mathrm{FU}(50 \mathrm{mg} / \mathrm{mL})$ is administered on a weekly basis for three to eight treatment sessions [6]. Intralesional injection of $1 \mathrm{~mL}$ of methotrexate in a concentration of 12.5 or $25 \mathrm{mg} / \mathrm{ml}$ every two to three weeks for one to four treatment sessions. Its administration prior to surgical excision also reduces the size of lesion. Injection of bleomycin and interferon alfa-2a and alfa-2b are also effective [7]. In all these, five injections are given per lesion, one into the center and one into each quadrant. It may lead to pain, erythema, necrosis, ulceration, crusting and rarely systemic side effects. Topical therapy with 5\% 5-FU daily and 5\% Imiquimod thrice weekly is effective. Other therapies include cryotherapy, argon laser and Er: YAG laser in combination with topical 5-FU, and photodynamic therapy [8].

In patients with multiple self-healing squamous epithelioma (MSSE) or generalized eruptive keratoacanthoma of Grzybowsky, oral acitretin (25 to $60 \mathrm{mg}$ per day) and isotretinoin (20 $\mathrm{mg}$ per day to $1.5 \mathrm{mg} / \mathrm{kg}$ per day) have been used. Other systemic therapies that have been used in a few patients with multiple KAs include methotrexate plus prednisone, cyclophosphamide and intravenous 5-FU. Serial zinc oxide wraps have been used.

\section{REFERENCES}

1. Broesby-Olsen S1, Bygum A, Gerdes AM, Brandrup F. Multiple self-healing squamous epithelioma of Ferguson-Smith: observations 


\section{www.odermatol.com}

in a Danish family covering four generations. Acta Derm Venereol. 2008;88:52-6.

2. Bose S, Morgan LJ, Booth DR, Goudie DR, Ferguson-Smith MA, Richards FM. The elusive multiple self-healing squamous epithelioma (MSSE) gene: further mapping, analysis of candidates, and loss of heterozygosity. Oncogene. 2006;25:806-12.

3. Chakrabarty KH, Perks AG. Ferguson-Smith syndrome: the importance of long term follow-up. Br J Plast Surg. 1996;49:497-8.

4. Karaa A, Khachemoune A. Keratoacanthoma: a tumor in search of a classification. Int J Dermatol. 2007;46:671.

5. Garcia-Zuazaga J, Ke M, Lee P. Giant keratoacanthoma of the upper extremity treated with mohs micrographic surgery: a case report and review of current treatment modalities. J Clin Aesthet Dermatol. 2009;2:22.

6. Kirby JS, Miller CJ. Intralesional chemotherapy for nonmelanoma skin cancer: a practical review. J Am Acad Dermatol. 2010;63:689.

7. Oh CK, Son HS, Lee JB, Jang HS, Kwon KS. Intralesional interferon alfa-2b treatment of keratoacanthomas. J Am Acad Dermatol. 2004;51:S177.

8. Alloo A, Garibyan L, LeBoeuf N, Lin G, Werchniak A, Hodi FS, et al. Photodynamic therapy for multiple eruptive keratoacanthomas associated with vemurafenib treatment for metastatic melanoma. Arch Dermatol. 2012;148:363.

Copyright by Yasmeen Jabeen Bhat. This is an open-access article distributed under the terms of the Creative Commons Attribution License, which permits unrestricted use, distribution, and reproduction in any medium, provided the original author and source are credited.

Source of Support: Nil, Conflict of Interest: None declared. 